\title{
X-linked spermine synthase gene (SMS) defect: the first polyamine deficiency syndrome
}

\author{
A Lauren Cason ${ }^{1}$, Yoshihiko Ikeguchi ${ }^{2}$, Cindy Skinner ${ }^{1}$, Tim C Wood ${ }^{1}$, Kenton R Holden ${ }^{1}$, \\ Herbert A Lubs ${ }^{3}$, Francisco Martinez ${ }^{4}$, Richard J Simensen ${ }^{1}$, Roger E Stevenson ${ }^{1}$, \\ Anthony E Pegg ${ }^{2}$ and Charles E Schwartz*,1
}

\begin{abstract}
${ }^{1} J . C$. Self Research Institute, Greenwood Genetic Center, 1 Gregor Mendel Circle, Greenwood, SC 29646, USA; ${ }^{2}$ Department of Cellular and Molecular Physiology, Pennsylvania State University, Hershey, PA 17033, USA; ${ }^{3}$ University of Miami, School of Medicine, Miami, FL 33101, USA; ${ }^{4}$ Unidad de Genética, Hospital Universitario La Fe, Valencia 46009, Spain
\end{abstract}

Polyamines (putrescine, spermidine, spermine) are ubiquitous, simple molecules that interact with a variety of other molecules in the cell, including nucleic acids, phospholipids and proteins. Various studies indicate that polyamines are essential for normal cell growth and differentiation. Furthermore, these molecules, especially spermine, have been shown to modulate ion channel activities of certain cells. Nonetheless, little is known about the specific cellular functions of these compounds, and extensive laboratory investigations have failed to identify a heritable condition in humans in which polyamine synthesis is perturbed. We report the first polyamine deficiency syndrome caused by a defect in spermine synthase (SMS). The defect results from a splice mutation, and is associated with the Snyder-Robinson syndrome (SRS, OMIM_309583), an X-linked mental retardation disorder. The affected males have mild-tomoderate mental retardation (MR), hypotonia, cerebellar circuitry dysfunction, facial asymmetry, thin habitus, osteoporosis, kyphoscoliosis, decreased activity of SMS, correspondingly low levels of intracellular spermine in lymphocytes and fibroblasts, and elevated spermidine/spermine ratios. The clinical features observed in SRS are consistent with cerebellar dysfunction and a defective functioning of red nucleus neurons, which, at least in rats, contain high levels of spermine. Additionally, the presence of MR reflects a role for spermine in cognitive function, possibly by spermine's ability to function as an 'intrinsic gateway' molecule for inward rectifier $\mathrm{K}^{+}$channels.

European Journal of Human Genetics (2003) 11, 937-944. doi:10.1038/sj.ejhg.5201072

Published online 24 September 2003

Keywords: spermine synthase; X-linked mental retardation; polyamine defect

\section{Introduction}

Polyamines are found ubiquitously in cells. ${ }^{1}$ They are synthesized by the actions of two aminopropyltransferases. These are spermidine synthase, which converts putrescine into spermidine, and spermine synthase (SMS), which converts spermidine into spermine. Both enzymes use decarboxylated S-adenosylmethionine as the aminopropyl

*Correspondence: Dr C E Schwartz. Tel: + 1864941 8140; Fax: + 1864 388 1703; E-mail: schwartz@ggc.org donor. The synthesis of polyamines is tightly regulated by alterations in the activities of the key enzymes ornithine decarboxylase and S-adenosylmethionine decarboxylase. ${ }^{2,3}$ Although they are simple molecules, polyamines appear to interact with a variety of molecules in the cell, including nucleic acids, phospholipids and protein. ${ }^{1,3}$ Polyamines have been implicated in many critical cellular processes including transcription, translation and alterations in enzymatic activities. Polyamines, particularly spermine, have also been shown to modulate ion channel activities. ${ }^{4,5}$ It is 
clear that polyamines are essential for normal cell growth and differentiation. Inactivation of either the ornithine decarboxylase or the S-adenosylmethionine decarboxylase genes in mice is lethal at early embryonic stages. ${ }^{6,7}$

A mouse model exists for SMS deficiency. The Gy mouse, in which this enzyme is deleted, exhibits neurological findings such as inner ear abnormalities, deafness hyperactivity and a circling behavior. ${ }^{8}$ Additionally, the Gy mouse has hypophosphatemic rickets and deletion of the $5^{\prime}$ end of the Phex gene. ${ }^{9}$ However, it is unlikely that the deletion of Phex contributes to the neurological findings, since two other mouse models for X-linked hypophosphatemic rickets, the Hyp mouse ${ }^{10}$ and the Ska1 mouse, ${ }^{11}$ do not have neurological symptoms. Therefore, although little is known about the specific cellular function of spermine, it was hypothesized that the neurological abnormalities found in Gy males were due to the deficiency of spermine. ${ }^{8}$ To test this hypothesis, mutation analysis of the human SMS gene, using denaturing highpressure liquid chromatography (DHPLC) technology, was undertaken in nine X-linked mental retardation (XLMR) families: five published families (Snyder-Robinson syndrome (SRS), ${ }^{12}$ Say syndrome, ${ }^{13}$ MRX33, ${ }^{14}$ MRX59, ${ }^{15}$ MRX73 ${ }^{16}$ ) and four unpublished families linked to the Xp22.1 region of the $X$ chromosome. In the SRS family, a point mutation, giving rise to aberrant splicing associated with decreased levels of SMS and cellular deficiency of spermine, was identified. This result represents the first human disorder linked to an inborn error of polyamine metabolism.

\section{Methods \\ RT-PCR}

Total RNA from Epstein-Barr virus (EBV)-transformed lymphoblastoid cell lines was isolated using Trizol (Life Technologies), and first-strand synthesis was performed using the Super Script first-strand synthesis system for RTPCR (Invitrogen). RT-PCR was performed in a $20 \mu \mathrm{l}$ reaction volume containing $10 \mu \mathrm{M}$ of each primer (exons $3-6 \mathrm{~F}$ and exons $3-6 \mathrm{R}$, Table 1 ), $250 \mu \mathrm{M}$ of dNTPs, $1 \times$ PCR buffer (Sigma) and $1 \mathrm{U}$ of Taq polymerase (Sigma) with $0.02 \mu \mathrm{M}$ of TaqStart $^{\mathrm{TM}}$ Antibody (Clontech). PCR conditions were initial denaturation at $95^{\circ} \mathrm{C}$ for $5 \mathrm{~min}$ followed by 30 cycles of $95^{\circ} \mathrm{C}$ for $30 \mathrm{~s}, 65^{\circ} \mathrm{C}$ for $30 \mathrm{~s}$ and $72^{\circ} \mathrm{C}$ for $30 \mathrm{~s}$, with a final extension at $72^{\circ} \mathrm{C}$ for $5 \mathrm{~min}$.

\section{Sequencing}

PCR amplicons from genomic DNA were gel purified using a QIAquick ${ }^{\mathrm{TM}}$ Gel Extraction Kit (QIAGEN). The purified DNA was sequenced using an automated laser florescence (ALF) DNA sequencer (Amersham Pharmacia Biotech), using the Thermosequenase $\mathrm{Cy}^{\mathrm{TM}} 5$ Dye Terminator Kit (Amersham Pharmacia Biotech) according to the manufacturer's protocol.

RT-PCR amplicons were subcloned using the TA-cloning kit (Invitrogen), and DNA from insert positive colonies were purified using a QIAprep Spin Miniprep Kit (250) (QIAGEN). Sequencing was carried out on the ALF as above, using primers exons 3-6F and exons 3-6R (Table 1). Sequence alignments and analyses were accomplished using the DNASTAR program (DNASTAR).

\section{DHPLC analysis}

Genomic DNA was amplified in a final reaction volume of $35 \mu \mathrm{l}$ using $50 \mathrm{ng}, 1 \times$ of the appropriate PCR buffer (Table 1), $2.0 \mathrm{~mm}$ dNTPs, $1.0 \mathrm{~mm}$ primers, $1 \mathrm{U}$ Taq polymerase (Sigma) and $0.02 \mu \mathrm{M}$ Taq antibody (Clontech). The PCR conditions were initial denaturation at $95^{\circ} \mathrm{C}$ for $5 \mathrm{~min}$ followed by 30 cycles of $95^{\circ} \mathrm{C}$ for $30 \mathrm{~s}$, the appropriate annealing temperature (Table 1 ) for $30 \mathrm{~s}$ and $72^{\circ} \mathrm{C}$ for $30 \mathrm{~s}$, with a final extension of $72^{\circ} \mathrm{C}$ for $5 \mathrm{~min}$.

For DHPLC analysis, $10 \mu \mathrm{l}$ each from two males with mental retardation $(\mathrm{MR})$ were mixed together and then

Table 1 Summary of primers and conditions for the PCR amplification and DHPLC analysis of the exons of spermine synthase

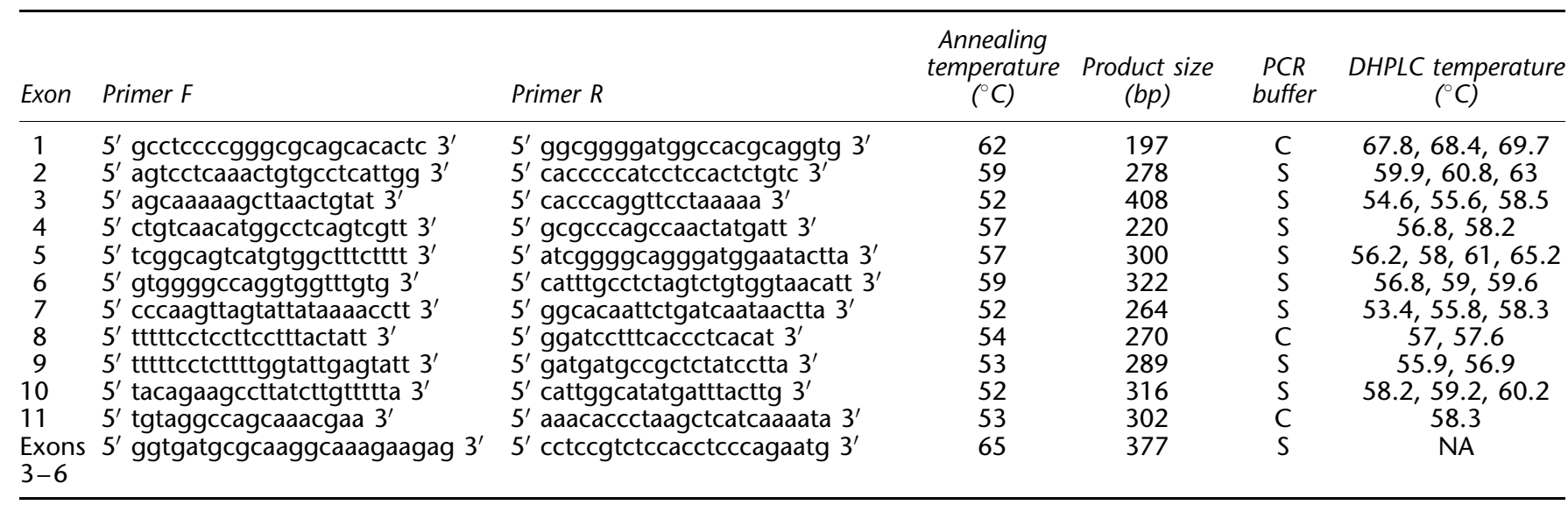

$\mathrm{S}=$ Sigma $\mathrm{C}=$ Master Amp C (Epicenter); NA = not applicable. 
heteroduplexed. As a control, DNA from two random males were mixed together and then heteroduplexed. DHPLC was performed on a WAVE DNA Fragment Analysis System (Transgenomic) containing a DNASep column (Transgenomic) held at the appropriate temperature for the particular amplicon (Table 1).

\section{HaeIII digestion}

A HaeIII restriction endonuclease site was created in the sequence containing $329+5 \mathrm{G}>\mathrm{A}$, by utilizing a primer to substitute a $\mathrm{G}$ for a $\mathrm{T}$ at position $329+6$. $^{3}$ Genomic DNA $(50 \mathrm{ng})$ was amplified in a final reaction volume of $35 \mu \mathrm{l}$, using $1 \times$ Mastep Amp K buffer (Epicenter) $2.0 \mathrm{~mm}$ dNTPs, $1.0 \mu \mathrm{M}$ primers (exon $4 \mathrm{~F} 15^{\prime}$ ctgtcaacatggcctcagtcgtt $3^{\prime}$ and exon 4(A)R $5^{\prime}$ aaggacattcaagagtggc $3^{\prime}$ ), $1 \mathrm{U}$ Taq Polymerase (Sigma) and $0.02 \mathrm{~mm}$ Taq antibody (Clontech). The PCR conditions were $95^{\circ} \mathrm{C}$ for $5 \mathrm{~min}$, followed by 35 cycles of $95^{\circ} \mathrm{C}$ for $30 \mathrm{~s}, 53^{\circ} \mathrm{C}$ for $30 \mathrm{~s}$ and $72^{\circ} \mathrm{C}$ for $30 \mathrm{~s}$, with a final extension of $72^{\circ} \mathrm{C}$ for $7 \mathrm{~min}$. The reaction $(10 \mu \mathrm{l})$ was then diluted to $20 \mu \mathrm{l}$ with $10 \mu \mathrm{l}$ of $2 \times$ HaeIII digestion buffer (New England Biolabs), $2 \times$ BSA (bovine serum albumin) and $2 \times$ spermidine. HaeIII $(1 \mu \mathrm{l} ; 10000 \mathrm{U} / \mathrm{ml}$, New England Biolabs) was added, and the digestion was carried out at $37^{\circ} \mathrm{C}$ overnight. After digestion, $10 \mu \mathrm{l}$ was loaded on a $2.5 \%$ agarose gel $\left(\right.$ Seaken ${ }^{\circledR}$ LE, BioWhittaker Molecular Applications) to separate the fragments.

\section{Polyamine analysis}

For both lymphoblastoid cells and fibroblasts, the cells were washed twice with PBS and harvested in $0.4 \mathrm{ml}$ of chilled $0.3 \mathrm{M}$ perchloric acid, and freeze-thawed twice. After centrifugation at $12000 \mathrm{~g}$ for $5 \mathrm{~min}$ at $4^{\circ} \mathrm{C}, 0.3 \mathrm{ml}$ of the supernatant was used for polyamine analysis, and the pellet was dissolved in $0.4 \mathrm{ml}$ of $0.3 \mathrm{M} \mathrm{NaOH}$ for protein determination, using Bio-Rad reagent with BSA as a standard. ${ }^{17}$ Polyamines were separated and quantified by HPLC with a postcolumn derivation to form fluorescent products. ${ }^{18,19}$

\section{SMS activity}

SMS assays were carried out using the method previously reported, in which the production of $\left[{ }^{35} \mathrm{~S}\right]$-methylthioadenosine from $\left[{ }^{35} \mathrm{~S}\right] \mathrm{dcAdoMet}$ and spermidine was measured. $^{20}$ Cells were harvested using spermidine/spermine synthase assay buffer ( $50 \mathrm{~mm}$ sodium phosphate, $\mathrm{pH} 7.2$, $0.3 \mathrm{~mm}$ EDTA, $10 \mathrm{~mm}$ 2-mercaptoethanol), and subjected to snap-freeze-thaw procedure three times. Cell extracts were then centrifuged at $4^{\circ} \mathrm{C}$ for $20 \mathrm{~min}$ at $12000 \mathrm{~g}$, before pooling the cytosolic extracts together. Protein measurements were carried out using Bio-Rad reagent with BSA as a standard. ${ }^{18}$

For SMS assays, cell extracts were added to an assay mix (500 $\mu \mathrm{M}$ spermidine, $100 \mathrm{~mm}$ sodium phosphate, $\mathrm{pH} 7.5$, $20 \mu \mathrm{M}$ S-adenosyl-1,8-diamino-3-thio-octane (AdoDato), $\left[{ }^{35} \mathrm{~S}\right]$ dcAdoMet $40000 \mathrm{cpm}$ of radioactivity per assay mix), and the reaction took place in a total volume of $200 \mu \mathrm{l}$. AdoDato, which is a transition-state-analogue inactivator of spermidine synthase, ${ }^{21}$ was added to prevent any spermidine synthase from contributing to the production of methylthioadenosine. Reactions were carried out at $37^{\circ} \mathrm{C}$ for $1 \mathrm{~h}$.

\section{Results}

The exon/intron boundaries of the 11 exons of SMS were determined by BLAST 2 analysis of the mRNA sequence (XM_054938) and genomic sequence (NT_011530). Primers were designed using DNASTAR (Table 1). DHPLC analysis detected an altered migration of the exon 4 amplicon in family K8145 (Figure 1a). The other eight probands were normal by this analysis. Sequence analysis of exon 4 from K8145 revealed a single base substitution, $\mathrm{G} \rightarrow \mathrm{A}$, at position +5 of the $5^{\prime}$ splice site of intron 4 $(329+5 \mathrm{G}>\mathrm{A})$ (Figure 1b). Since the alteration did not create or destroy any restriction endonuclease site, a modified primer was designed to create a HaeIII site (GGCC/CCGG) in the altered sequence, by substituting a $\mathrm{G}$ for a $\mathrm{T}$ at position $329+6 .^{22}$ Using HaelII digestion, it could be shown that the $329+5 \mathrm{G}>\mathrm{A}$ change in K8145 segregated with affected status (Figure 1c). Utilizing the HaeIII digestion, the change was not observed in $480 \mathrm{X}$ chromosomes from normal adult males, indicating that it was not likely a rare polymorphism. ${ }^{23}$

\section{SMS gene analysis}

Based on the segregation and population data, further analysis of the $329+5 \mathrm{G}>\mathrm{A}$ nucleotide alteration was conducted. The $\mathrm{G} \rightarrow \mathrm{A}$ substitution changed the splice consensus sequence at the exon 4/intron 4 boundary from CGgtaagt to CGgtaaat, with a concomitant lowering of the splice consensus value (CV) from 0.91 to $0.77 .{ }^{24}$ Owing to the reduction in the CV, RT-PCR analysis, using primers in exons 3 and 6 (Table 1), was performed on cDNA isolated from lymphoblastoid cells of an affected male (IV-10; Figure 1c). Two bands, one of the expected size and the other smaller in size, were observed on agarose gel electrophoresis from this male, while cDNA from a normal male exhibited only a single band of the expected size (Figure 2a). Sequence analysis of the lower band in patient IV-10 revealed the absence of exon 4, while sequence analysis of the upper band was consistent with proper splicing (Figure 2b). The sequence of the smaller band is predicted to produce a protein missing 22 amino acids from exon 4, and 22 novel amino acids prior to truncation at position 111 (Figure 2c).

\section{SMS activity and spermine levels}

To further substantiate the pathogenic nature of the $329+5$ G $>$ A mutation, the activity of SMS and the levels of spermidine and spermine were measured in the 


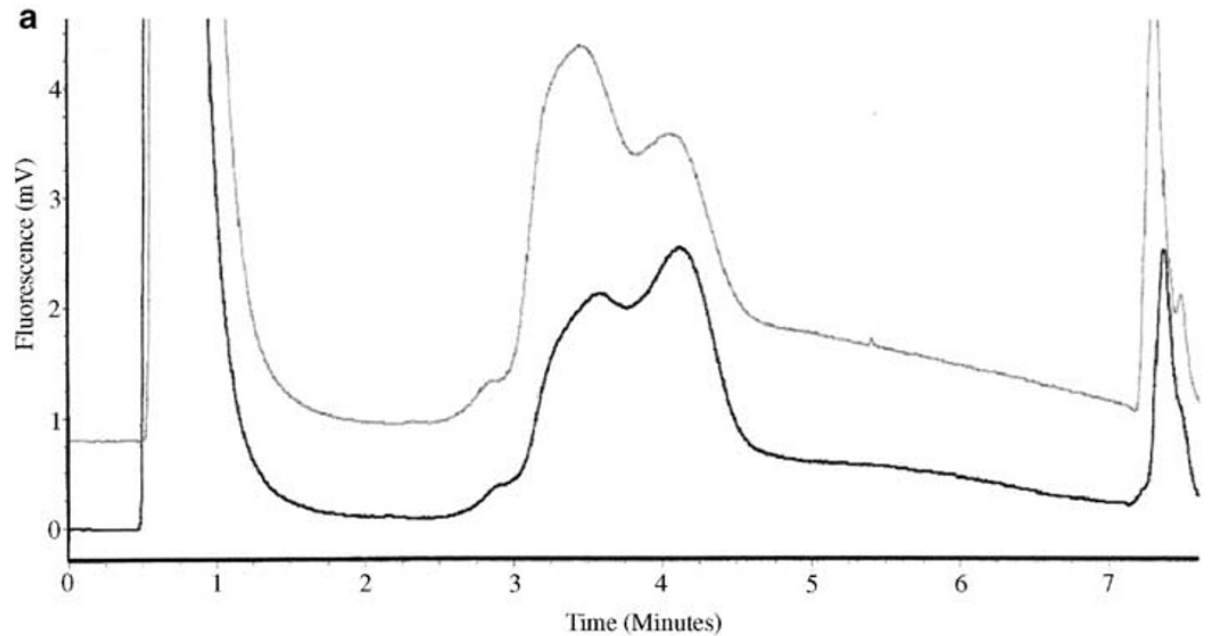

b Mutation

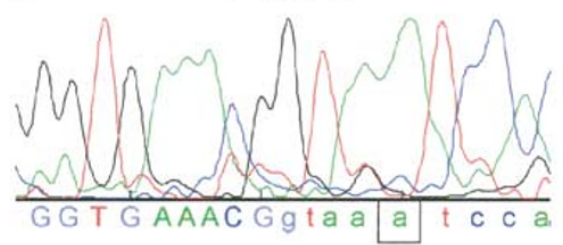

Normal

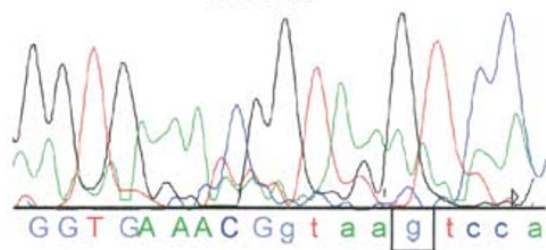

\section{c}

\section{K8145}
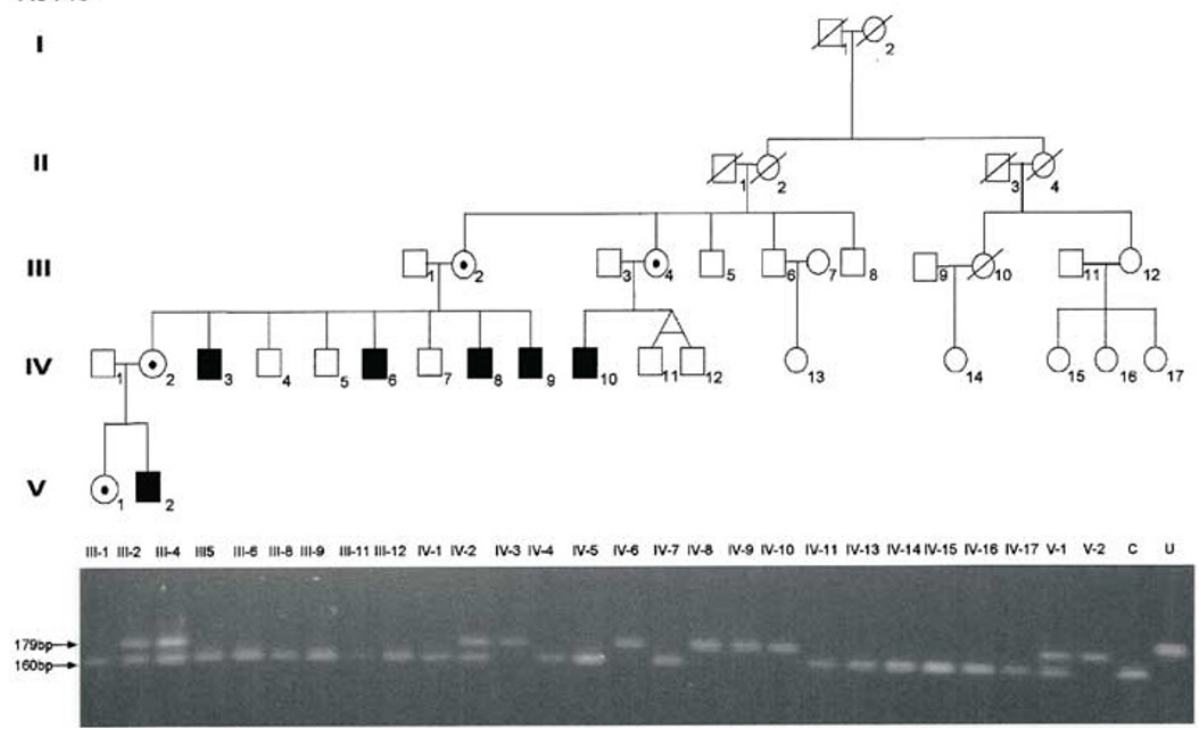

Figure 1 Mutation analysis in family K8145. (a) DHPLC chromatograph of the PCR product corresponding to exon 4 of the SMS gene. The upper trace is from an affected male, IV-2. The lower trace is from a control male. (b) Automated sequence traces showing the $329+5 \mathrm{G}>\mathrm{A}$ nucleotide substitution, normal nucleotide sequence in a control male and person IV-2 in K8145. (c) Gel electrophoresis of fragments resulting from a Haell digestion of a PCR product of exon 4 showing cosegregation of the upper band (179 bp) with affected status in family K8145. The lower band (160 bp) represents the normal allele. The carrier females exhibit both the normal band $(160 \mathrm{bp})$ and the mutant allele band (179 bp). Open squares are normal males; black squares are affected males; open circles are normal females; circles with dots are carrier females; the c lane is a normal random male; the u lane is undigested. 

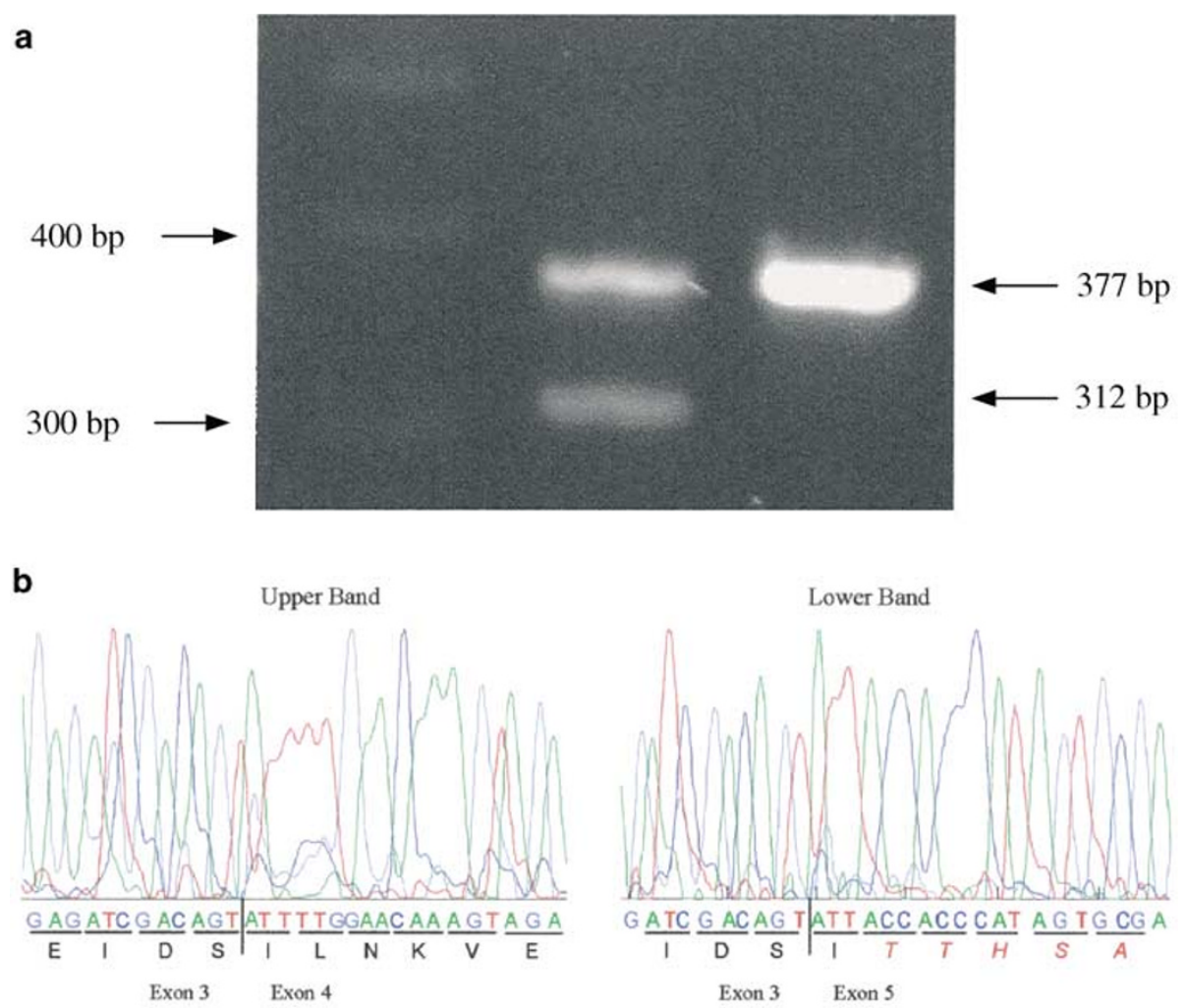

\section{C}

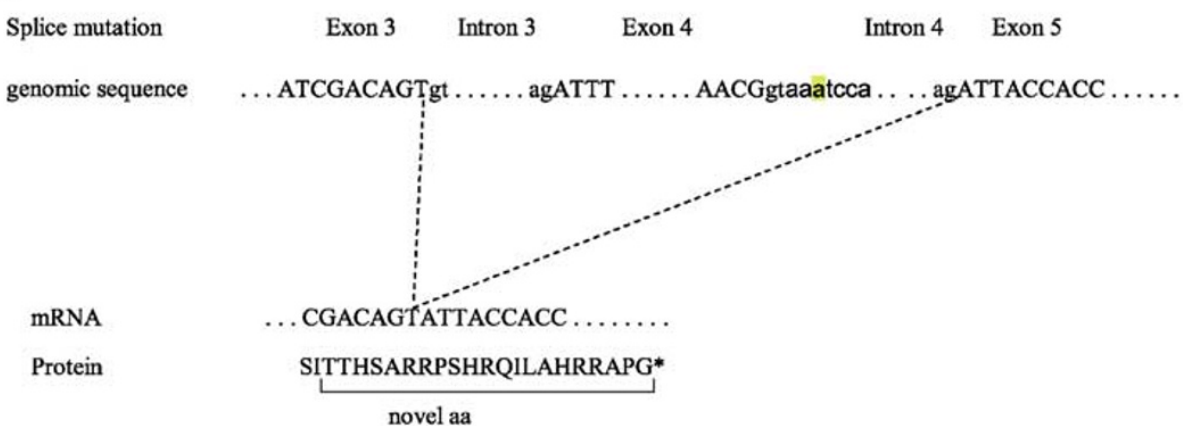

Figure 2 RT-PCR analysis of the SMS gene in K8145. (a) Gel electrophoresis of RT-PCR products of affected male IV-10 (lane 1) and a normal random male (lane 2). The upper band of $377 \mathrm{bp}$ is the expected size. The lower band of $312 \mathrm{bp}$ in person IV10 is abnormal. The RT-PCR products were generated using primers exons 3-6 (Table 1). (b) Automated sequence traces showing the normal CDNA sequence of the upper band with correct splicing of exons 3 and 4 and the cDNA sequence of the lower band showing the splicing out of exon 4 and the respective translated amino acid. Amino acids shown in red italics are due to a frame shift caused by the splicing out of exon 4. (c) The aberrant splicing event predicted in family K8085. The predicted amino acid sequence for the altered SMS protein is given below the novel mRNA sequence.

lymphoblastoid cells obtained from established cell lines of two affected males, IV-10 and V-2 (Table 2). The activity of SMS was found to be $5 \%$ of controls. Additionally, the spermidine/spermine ratio was about 2.5-fold that of controls, due to a $50 \%$ reduction in spermine levels and a $75 \%$ increase in spermidine levels (Table 2). To explore whether this defect was limited to lymphocytes, skin fibroblast cultures were established from two affected males (IV-6, IV-9, Figure 1c). Abnormalities were noted in
SMS activity, which was greatly reduced, as well as in the spermidine/spermine ratio and the levels of the individual polyamines (Table 2). Thus, the spermine deficiency was not limited to one cell type.

\section{Mutation screen}

An attempt was made to determine the frequency of SMS mutations in the MR population. DHPLC analysis of the 11 
Table 2 Spermidine/spermine ratios and levels of spermine synthase activity in lymphoblastoid cell lines and fibroblasts in controls and affected males in family K8145

\begin{tabular}{|c|c|c|c|c|c|c|c|c|c|c|}
\hline \multirow[b]{2}{*}{ Sample } & \multicolumn{5}{|c|}{ Lymphoblasts ( $\mathrm{nmol} / \mathrm{mg}$ protein) ${ }^{\mathrm{a}}$} & \multicolumn{5}{|c|}{ Fibroblasts (nmol/mg protein) ${ }^{\mathrm{a}}$} \\
\hline & Put & Spd & Spm & $\begin{array}{l}\text { Spd/ } \\
\text { Spm }\end{array}$ & $\begin{array}{l}\text { Spm synthase } \\
\text { activity }(c p m \text { MTA/ } \\
\mu g \text { protein/h) }\end{array}$ & Put & Spd & Spm & $\begin{array}{l}\text { Spd/ } \\
\text { Spm }\end{array}$ & $\begin{array}{l}\text { Spm synthase }{ }^{b} \\
\text { activity }(\text { cpm MTA/ } \\
\mu g \text { protein/h) }\end{array}$ \\
\hline Control & 4.03 & 7.07 & 7.71 & 0.92 & 1484 & 3.8 & 14.1 & 15.4 & 0.92 & 437 \\
\hline Control & 4.37 & 7.10 & 7.25 & 0.98 & 1033 & 4.2 & 19.4 & 19.5 & 0.99 & 457 \\
\hline $\begin{array}{l}\text { Male IV- } \\
10\end{array}$ & 1.24 & 11.75 & 4.44 & 2.63 & 71 & & & & & \\
\hline Male V-2 & 1.86 & 14.43 & 4.64 & 3.11 & 73 & & & & & \\
\hline Male IV-6 & 0.63 & 28.70 & 16.50 & 1.73 & $17^{\mathrm{C}}$ & 1.7 & 34.0 & 15.2 & 2.20 & 63 \\
\hline Male IV-9 & 0.93 & 36.60 & 19.10 & 1.92 & $22^{c}$ & 1.3 & 27.1 & 12.3 & 2.20 & 49 \\
\hline Male IV-3 & 0.63 & 27.30 & 15.50 & 1.75 & $22^{c}$ & & & & & \\
\hline Male IV-8 & 0.89 & 31.40 & 18.10 & 1.73 & $20^{c}$ & & & & & \\
\hline Controls ${ }^{\mathrm{d}}$ & 3.10 & 16.00 & 25.90 & 0.62 & $484^{\mathrm{C}}$ & & & & & \\
\hline
\end{tabular}

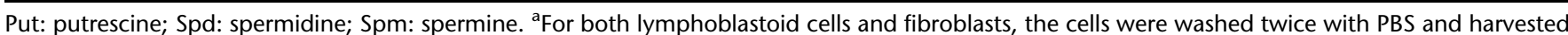
in $0.4 \mathrm{ml}$ of chilled $0.3 \mathrm{M}$ perchloric acid, and freeze-thawed twice. After centrifugation at $12000 \mathrm{~g}$ for $5 \mathrm{~min}$ at $4^{\circ} \mathrm{C}, 0.3 \mathrm{ml}$ of the supernatant was used for polyamine analysis, and the pellet was dissolved in $0.4 \mathrm{ml}$ of $0.3 \mathrm{M} \mathrm{NaOH}$ for protein determination using Bio-Rad reagent with BSA as a standard. ${ }^{17}$ Polyamines were separated and quantified by HPLC with a postcolumn derivation to form fluorescent products. ${ }^{18}$ b ${ }^{5}$ permine synthase assays were carried out using the method previously reported. ${ }^{20}$ Cells were harvested using spermidine/spermine synthase assay buffer (50 mM sodium phosphate, $\mathrm{pH}$ 7.2, $0.3 \mathrm{mM}$ EDTA, $10 \mathrm{mM}$ 2-mercaptoethanol), and subjected to snap-freeze-thaw procedure three times. Cell extracts were then centrifuged at $4{ }^{\circ} \mathrm{C}$ for $20 \mathrm{~min}$ at $12000 \mathrm{~g}$ before pooling cytosolic extracts together. Protein measurements were carried out using Bio-Rad reagent with BSA as a standard. ${ }^{21}$ Cell extracts were added to an assay mix (500 $\mu \mathrm{M}$ spermidine, $100 \mathrm{mM}$ sodium phosphate, pH 7.5, 20 $\mu \mathrm{M}$ S-adenosyl-1,8-diamino-3-thiooctane (AdoDato), $\left[{ }^{35} \mathrm{~S}\right] \mathrm{dcAdoMet} 40000 \mathrm{cpm}$ of radioactivity per assay mix), and the reaction was conducted in a total volume of $200 \mu \mathrm{l}$. To prevent the measurement of enzymic activity resulting from endogenous putrescine, $20 \mu \mathrm{M}$ AdoDato, a transition-state-analogue inactivator of spermidine synthase, was added. ${ }^{21}$ Reactions were carried out at $37^{\circ} \mathrm{C}$ for $1 \mathrm{~h}$. 'Separate set of experiments using [35S] dcAdoMet of lower specific activity. ${ }^{d}$ Average of six people.

SMS exons in 130 males with nonfragile X MR failed to detect any mutations.

\section{Discussion}

XLMR accounts for $10-15 \%$ of all cases of MR present in humans. $^{25}$ XLMR entities can be separated into two groups: those that are syndromic, MRXS, and those that are nonsyndromic, MRX. ${ }^{26}$ The separation is based on the presence (MRXS) or absence (MRX) of distinctive somatic, metabolic neurological or behavioral features in association with the MR. Both syndromal and nonsyndromal forms of XLMR have been localized to all regions of the X chromosome. $^{27,28}$ Molecular studies have begun to give some idea of the number of genes on the $\mathrm{X}$ chromosome that influence intelligence. In all, 33 genes have been associated with syndromic XLMR and, in the case of MECP2, XNP, ARX, FGDY1, AGTR2 and RSK2, occasionally with nonsyndromic XLMR. Nine additional genes have been associated with only nonsyndromic XLMR. A total of 47 additional XLMR syndromes have been mapped, but the genes have not been identified, and over 50 XLMR syndromes have yet to be mapped. Also, the genes for 60 of the MRX families, comprising 10 nonoverlapping linkage regions, have yet to be identified. ${ }^{29}$

It is anticipated that most of the distinctive XLMR syndromes will be caused by different genes, and that at least 10 additional nonsyndromic XLMR genes will be found. Hence, a minimal estimate of the total number of
XLMR genes, those that cause nonsyndromic and syndromic XLMR, will be in excess of 150 , and thus represent at least $11 \%$ of the genes on the $X$ chromosome. ${ }^{30}$

Family K8145 was initially reported by Snyder and Robinson $^{31}$ as a nonsyndromic XLMR entity (OMIM_309583), in which affected males had hypotonia and unsteady gait in addition to MR. In total, 11 males in four generations had mild to moderate intellectual impairment. The syndrome was mapped to Xp22 (maximal twopoint lod score of 4.2 for DXS989 located telomeric to the Duchenne muscular dystrophy locus). ${ }^{12}$ Additional clinical findings at the time of the last follow-up in 1994 included facial asymmetry, narrow or cleft palate, nasal dysarthric speech, diminished muscle mass, kyphoscoliosis, osteoporosis and long great toes. ${ }^{12}$ Recent clinical evaluations from 2002 found the affected males to have an unsteady gait, movement disorder and some seizures. In selected individuals, microscopic examination of muscle, EKG, brain MRI and serum electrolytes were normal. Two males (III-9, IV-4) out of four had abnormal electroencephalograms.

It is noteworthy that the marked reduction in SMS seen in the cell lines from Snyder-Robinson patients was not associated with a parallel reduction in spermine, or in the total polyamine content of the cells (Table 2 ). However, the spermidine/spermine ratio was more than doubled, suggesting that compensatory changes in other enzymes in the polyamine biosynthetic pathway, which is known to be very highly regulated, ${ }^{2,3}$ occur to maintain some level of 
spermine at the expense of reducing putrescine and increasing spermidine. Further studies will be needed to identify the nature of the compensatory changes, but an increased supply of decarboxylated S-adenosylmethionine is a likely alteration, since S-adenosylmethionine decarboxylase is known to be repressed by spermine. ${ }^{32,33}$ Treatment with low levels of inhibitors of SMS leads to changes in polyamines similar to those seen in the cell lines from Snyder-Robinson patients with a decrease in putrescine, an increase in spermidine and a fall in spermine. ${ }^{18,19}$ Such inhibitor exposure does lead to an increase in S-adenosylmethionine decarboxylase activity. ${ }^{33}$

It is possible that the extent of reduction in SMS activity in the tissues of Snyder-Robinson males varies with the cell type under consideration, since the degree to which the small extent of correct splicing occurs may depend on cellular factors. It is also possible that the degree to which the compensatory changes described above are able to normalize the spermine levels despite the reduction in SMS are tissue or cell dependent. However, it is very likely that there is a general alteration in polyamine levels in the tissues of affected males with reductions in putrescine and spermine, and an increase in spermidine similar to those seen in the fibroblast and lymphoblastoid cells. In view of the many well-documented effects of polyamines on cell growth differentiation and neurological function, ${ }^{34-36}$ these changes are likely to be responsible for the SnyderRobinson phenoptype.

The clinical presentation of the male patients with the $329+5 \mathrm{G}>\mathrm{A}$ mutation in SMS is less severe than the phenotype of the Gy mutant mouse: circling behavior, inner ear abnormalities, deafness, hyperactivity, small at birth, reduced viability. ${ }^{8,37}$ This difference may be because (1) the mutation in K8145 substantially reduced the amount of normal spermine but did not totally eliminate its production, as observed in the Gy mouse, ${ }^{8,37}$ and (2) the Gy mutant results from the deletion of both Sms and Phex, which may compound the phenotype expected from the deletion of only Sms. ${ }^{8}$

However, although the clinical presentation of the patients is different from that observed in the Gy mouse, it is consistent with localization data for spermine obtained in the rat. ${ }^{38}$ Using immunocytochemical methods, Laube et $\mathrm{al}^{38}$ demonstrated a lack of ubiquitous staining of spermidine/spermine in the adult rat brain. The strongest neuronal staining was observed in the hypothalamic paraventricular, supraoptic and accessory neurosecretory nuclei, while strong cytoplasmic staining was seen in the mesencephalic trigeminal tract, the red nucleus and large motor neurons of the spinal cord.

Relative to the clinical presentation, the red nucleus in humans is an integral part of the cerebellar circuitry, which affects balance, posture, motor coordination, locomotion, tone, speech and possibly cognitive ability. Patients with Snyder-Robinson XLMR syndrome have an unsteady gait, hypotonia and decreased muscle mass, speech abnormalities, and movement disorders consistent with cerebellar circuitry/red nucleus dysfunction. Although affected males had normal microscopic muscle, EKG, serum electrolytes and brain MRI studies, these findings would not be unexpected, since the spermine deficiency likely gives rise to a neurotransmitter/circuitry problem.

Previously, it had been noted that women in family K8145 exhibited skewed X inactivation due to a promoter mutation in the XIST gene. ${ }^{39}$ The skewing ranged from 90:10 (IV-1) to 65:35 (V-1). Since both of these women are carriers of the $329+5 \mathrm{G}>\mathrm{A}$ mutation, it is clear the $\mathrm{X}$ inactivation is not related to the SMS mutation. Furthermore, both women, who are mother and daughter, appear similarly normal; hence, the $\mathrm{X}$ inactivation is not working as a protective mechanism.

The deficiency of spermine in a family with the SnyderRobinson XLMR syndrome is the first clear indication of a role for polyamines in brain development and cognitive function. Polyamines, particularly spermine, have been shown to modulate ion channel activities. ${ }^{4,5}$ Our finding supports the important role of spermine as an intrinsic gateway' molecule for inward rectifier $\mathrm{K}^{+}$channels. Thus, as intracellular levels of spermine decrease, so does the excitability of the cell membrane. ${ }^{4}$ Additionally, in other cells with AMPA receptors, excitability is increased along with an increase in the $\mathrm{Ca}^{2+}$ flux causing $\mathrm{Ca}^{2+}$ overload. ${ }^{40}$ Any one of these alterations, which could result either from the reduction in spermine or the alteration in the relative contents of the polyamines, is likely to adversely affect the function of neuronal cells. Although the level of spermidine does increase, possibly to compensate for the lower level of spermine, spermidine does not adequately substitute for spermine, since its binding efficiency to $\mathrm{K}^{+}$ channels is 100 -fold less. ${ }^{40}$

At present, it is difficult to predict the frequency of SMS mutations in the male MR population. A screen of genomic DNA of 130 males with nonfragile X MR detected no mutations. Nonetheless, any male with MR of unknown causation can now be tested for an elevated spermidine/ spermine ratio and a low level of SMS.

Based on the Gy mutant phenotype, it may be that any loss of function mutation in SMS leads to lethality. Therefore, in addition to the male MR population, male fetal deaths of unknown cause, male newborns with hypotonia and exhibiting a failure to thrive, or males who present with signs of cerebellar circuitry dysfunction and some mental impairment, may warrant SMS testing.

\section{Acknowledgements}

We would like to express our gratitude to members of K8145 for their participation over a 10-year period. We would also like to acknowledge Dr Ralph Meyer, who first suggested SMS to CES as a candidate XLMR gene in 1998. Drs Nancy Carpenter and Elke Holinski-Feder contributed DNA from the Say syndrome and MRX33 families, 
respectively. Tonya Moss maintained the lymphoblastoid cell lines and prepared mRNA. Mary Alice Moore established and maintained the fibroblast cell lines. Susan Daniels of the Core Facility of the Center for Molecular Studies at the Greenwood Genetic Center performed the sequencing reactions. Susi Sass-Kuhn carried out the polyamine analysis and Anne Pruznak performed some of the spermine synthase assays. The manuscript was prepared by Joy Driggers. The research was supported by grants HD26202 from NICHD (CES), MH57840 from NIMH (RES and CES), GM-26290 from NIGMS (AEP) and a grant from the South Carolina Department of Disabilities and Special Needs. This paper is dedicated to the memory of Ethan Francis Schwartz (1996-1998).

\section{References}

1 Cohen SS: A Guide to the Polyamines. New York: Oxford University Press, 1998.

2 Coffino P: Regulation of cellular polyamines by antizyme. Nat Rev Mol Cell Biol 2001; 2: 188-194.

3 Pegg AE: Recent advances in the biochemistry of polyamines in eukaryotes. Biochem J 1986; 234: 249-262.

4 Williams K: Interactions of polyamines with ion channels. Biochem J 1997; 325 (Part 2): 289-297.

5 Nichols CG, Lopatin AN: Inward rectifier potassium channels. Annu Rev Physiol 1997; 59: 171-191.

6 Pendeville H, Carpino N, Marine JC et al: The ornithine decarboxylase gene is essential for cell survival during early murine development. Mol Cell Biol 2001; 21: 6549-6558.

7 Nishimura K, Nakatsu F, Kashiwagi K, Ohno H, Saito T, Igarashi K: Essential role of S-adenosylmethionine decarboxylase in mouse embryonic development. Genes Cells 2002; 7: 41-47.

8 Meyer Jr RA, Henley CM, Meyer MH et al: Partial deletion of both the spermine synthase gene and the Pex gene in the X-linked hypophosphatemic, gyro (Gy) mouse. Genomics 1998; 48: 289-295.

9 Lyon MF, Scriver CR, Baker LR, Tenenhouse HS, Kronick J, Mandla S: The Gy mutation: another cause of X-linked hypophosphatemia in mouse. Proc Natl Acad Sci USA 1986; 83: 4899-4903.

10 Eicher EM, Southard JL, Scriver CR, Glorieux FH: Hypophosphatemia: mouse model for human familial hypophosphatemic (vitamin D-resistant) rickets. Proc Natl Acad Sci USA 1976; 73: 4667-4671.

11 Carpinelli MR, Wicks IP, Sims NA et al: An ethyl-nitrosoureainduced point mutation in phex causes exon skipping, X-linked hypophosphatemia, and rickets. Am J Pathol 2002; 161: 1925-1933.

12 Arena JF, Schwartz C, Ouzts L et al: X-linked mental retardation with thin habitus, osteoporosis, and kyphoscoliosis: linkage to Xp21.3-p22.12. Am J Med Genet 1996; 64: 50-58.

13 Say B, Meyer J: Familial trigonocephaly associated with short stature and developmental delay. Am J Dis Child 1981; 135: 711-712.

14 Holinski-Feder E, Golla A, Rost I, Seidel H, Rittinger O, Meindl A: Regional localization of two MRX genes to Xq28 (MRX28) and to Xp11.4-Xp22.12 (MRX33). Am J Med Genet 1996; 64: 125-130.

15 Carpenter NJ, Brown WT, Qu Y, Keenan KL: Regional localization of a nonspecific X-linked mental retardation gene (MRX59) to Xp21.2-p22.2. Am J Med Genet 1999; 85: 266-270.

16 Martinez F, Martinez-Garay I, Millan JM et al: Localization of nonspecific X-linked mental retardation gene (MRX73) to Xp22.2. Am J Med Genet 2001; 102: 200-204.

17 Bradford MM: A rapid and sensitive method for the quantitation of microgram quantities of protein utilizing the principle of protein-dye binding. Anal Biochem 1976; 72: 248-254.

18 Seiler N, Knodgen B: Determination of amino acids by separation of their ion pairs with dodecyl sulphate. J Chromatogr 1985; 341: $11-21$.
19 Pegg AE, Wechter R, Poulin R, Woster PM, Coward JK: Effect of S-adenosyl-1,12-diamino-3-thio-9-azadodecane, a multisubstrate adduct inhibitor of spermine synthase, on polyamine metabolism in mammalian cells. Biochemistry 1989; 28: $8446-8453$

20 Wiest L, Pegg AE: Assay of spermidine and spermine synthases. Methods Mol Biol 1998; 79: 51-57.

21 Tang KC, Pegg AE, Coward JK: Specific and potent inhibition of spermidine synthase by the transition-state analog, S-adenosyl-3thio-1,8-diaminooctane. Biochem Biophys Res Commun 1980; 96: $1371-1377$.

22 Haliassos A, Chomel JC, Grandjouan S, Kruh J, Kaplan JC, Kitzis A: Detection of minority point mutations by modified PCR technique: a new approach for a sensitive diagnosis of tumor-progression markers. Nucleic Acids Res 1989; 17: 8093-8099.

23 Collins JS, Schwartz CE: Detecting polymorphisms and mutations in candidate genes. Am J Hum Genet 2002; 71: 1251-1252.

24 Cooper D, Krawczak M: Human Gene Mutation. Oxford: BIOS Scientific Publisher Limited, 1995, , vol B105, UK edn.

25 Stevenson RE, Schwartz CE, Schroer RJ: X-Linked Mental Retardation. New York: Oxford University Press, 2000.

26 Neri G, Gurrieri F, Gal A, Lubs HA: XLMR genes: update 1990. Am J Med Genet 1991; 38: 186-189.

27 Lubs H, Chiurazzi P, Arena J, Schwartz C, Tranebjaerg L, Neri G: XLMR genes: update 1998. Am J Med Genet 1999; 83: 237-247.

28 Chiurazzi P, Hamel BC, Neri G: XLMR genes: update 2000. Eur J Hum Genet 2001; 9: 71-81.

29 Stevenson RE, Schwartz CE: Clinical and molecular contributions to the understanding of X-linked mental retardation. Cytogenet Genome Res, (in press).

30 Accessed September 10, 2002: National Center for Biotechnology Information: The Human Genome http:// www.ncbi.nlm.nih.gov/genome/guide/human, 2003.

31 Snyder RD, Robinson A: Recessive sex-linked mental retardation in the absence of other recognizable abnormalities. Report of a family. Clin Pediatr (Philadelphia) 1969; 8: 669-674.

32 Pegg AE, Coward JK: Effect of $N$-(n-butyl)-1,3-diaminopropane on polyamine metabolism, cell growth and sensitivity to chloroethylating agents. Biochem Pharmacol 1993; 46: 717-724.

33 Pegg AE, Xiong H, Feith DJ, Shantz LM: S-adenosylmethionine decarboxylase: structure, function and regulation by polyamines. Biochem Soc Trans 1998; 26: 580-586.

34 Heby O: Role of polyamines in the control of cell proliferation and differentiation. Differentiation 1981; 19: 1-20.

35 Kauppinen RA, Alhonen LI: Transgenic animals as models in the study of the neurobiological role of polyamines. Prog Neurobiol 1995; 47: 545-563.

36 Thomas T, Thomas TJ: Polyamines in cell growth and cell death: molecular mechanisms and therapeutic applications. Cell Mol Life Sci 2001; 58: 244-258.

37 Mackintosh CA, Pegg AE: Effect of spermine synthase deficiency on polyamine biosynthesis and content in mice and embryonic fibroblasts, and the sensitivity of fibroblasts to 1,3-bis(2-chloroethyl)- $N$-nitrosourea. Biochem $J$ 2000; 351 (Part 2): 439-447.

38 Laube G, Bernstein HG, Wolf G, Veh RW: Differential distribution of spermidine/spermine-like immunoreactivity in neurons of the adult rat brain. J Comp Neurol 2002; 444: 369-386.

39 Plenge RM, Hendrich BD, Schwartz C et al: A promoter mutation in the XIST gene in two unrelated families with skewed X-chromosome inactivation. Nat Genet 1997; 17: 353-356.

40 Aizenman CD, Munoz-Elias G, Cline HT: Visually driven modulation of glutamatergic synaptic transmission is mediated by the regulation of intracellular polyamines. Neuron 2002; 34: $623-634$. 